\title{
Factors influencing dividend payout decisions: Evidence from South Africa
}

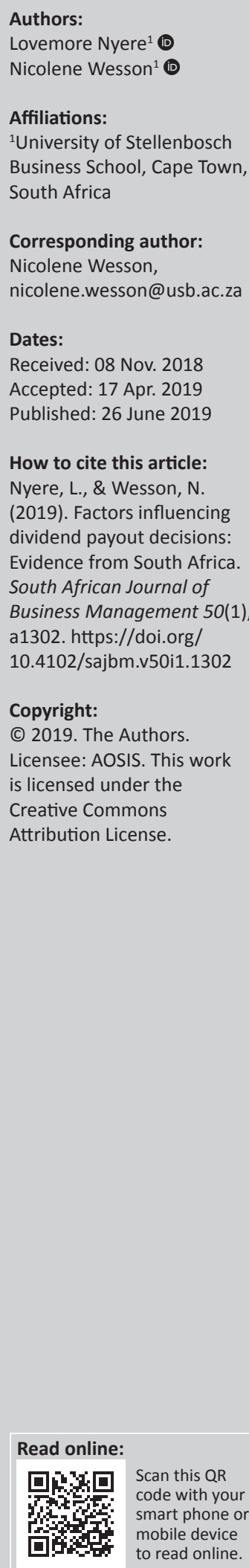

Background: Dividend payout is one of the most debated contemporary corporate finance issues. No universal theoretical model describes the factors that corporate managers consider in dividend payout decisions. This study extends previous South African empirical research on dividend payout trends and motivations for Johannesburg Stock Exchange (JSE)-listed industrial companies over the period 1999-2014. The study period coincides with the introduction of share repurchases as an alternative distribution method, covers multiple dividend distribution regulatory amendments and overlaps the global financial crisis of 2008 .

Objectives: The aim of this study was to ascertain whether the global financial crisis of 2008 affected dividend payouts and to identify factors that influenced dividend payout decisions of JSE-listed industrial companies over the period 1999-2014.

Method: Descriptive statistics and a fixed-effects panel regression analysis were applied to dividend data extracted from published annual reports of JSE-listed industrial companies over the period 1999-2014.

Results: Dividend distributions of JSE-listed industrial companies increased over the study period in contrast to declining global dividend distribution trends. A significant increase in dividend payout was found when comparing pre- and post-recession periods, in line with the positive impact of dividend distribution regulatory reforms. Company size (+), profitability (+), sales growth (-) and free cash flow (-) were identified as significant factors that influence dividend distributions of JSE-listed industrial companies.

Conclusion: The results offer support for the company life cycle hypothesis, the taxes and clientele hypothesis and corporate managers' preference for stable dividend policies.

Keywords: Dividends; dividend payout; dividend trends; company life cycle hypothesis; taxes and clientele hypothesis.

\section{Introduction}

Dividend payout decisions remain one of the most fundamental finance problems that keep puzzling researchers. This has been a subject of debate in financial literature since Miller and Modigliani (1961) concluded that dividend payout is irrelevant in perfect capital markets. Despite extensive research and an increasing number of factors identified in the literature as determinants of dividend payout, there is no universal, conclusive explanation on how companies make dividend payout decisions (Al-Malkawi, Rafferty, \& Pillai, 2010; Baker \& Weigand, 2015). The determinants of dividend payout cannot be reduced to a single universal model because of varying sensitivities to country-, company- and market-specific characteristics (Baker \& Weigand, 2015).

South Africa is no exception to this corporate finance problem. An increasing number of companies in South Africa are still paying cash dividends and investors pay close attention to dividend payout announcements (Makka, 2014; Viviers, Firer, \& Muller, 2013; Wesson, Bruwer, \& Hamman, 2015). Generally, investors react negatively to dividend reductions by South African listed companies (Lentsoane, 2012). This is characteristic of contemporary financial markets that are distinguished by information asymmetry, and prudent and, often, irrational investors (Borges, 2008).

The question that arises is the following: What are the factors that South African companies consider when making dividend payout decisions? This study answers this question by analysing dividend payout trends of industrial companies listed on the Johannesburg Stock Exchange (JSE) for the period 1999-2014. Factors influencing dividend payments have been extensively researched 
in developed countries, but limited evidence from emerging markets such as South Africa exists (Forti, Peixoto, \& Alves, 2015). On the African continent, efforts are continuing to deepen liquidity and to provide investment opportunities to foreign and domestic investors (PwC, 2017). Understanding the country-, company- and market-specific behaviour pertaining to dividend payout decisions is therefore pertinent to all capital markets' participants.

The timeframe of the present study was characterised by a number of regulatory changes (e.g. the introduction of share repurchases as an alternative distribution method, the strengthening of liquidity and solvency requirements pertaining to distributions and the change to a dividend withholding tax [DWT] regime) affecting dividend distributions in South Africa, as well as the impact of the global financial crisis of 2008. These changes offered research opportunities to understand the factors influencing corporate dividend distribution trends of JSE-listed industrial companies.

This study is expected to provide greater insights for corporate managers, investors and government regulatory authorities into the dividend payout behaviour of JSE-listed industrial companies. Corporate managers may use the results of the study to formulate dividend payout policies based on the emerging dividend distribution trends. Investors seeking to construct dividend income investment portfolios will enhance their ability to select high-quality stocks within JSE-listed industrial companies. Compliance regulators, such as government authorities, will obtain an understanding of the impact of the regulatory changes on corporate dividend distribution behaviour and the operation of financial markets.

The study is structured as follows: the next section provides a review of relevant global and South African theoretical dividend payout literature, followed by the research method, the reported results and finally the concluding remarks.

\section{Literature review}

When a company realises net profit after tax, it can reinvest the profit in current operations, distribute the profit to shareholders in the form of dividends, pay off existing debt or use the funds to repurchase its shares from the shareholders. Therefore, the decision to distribute available profits is a very important one because it can affect the value of the company (Firer, Ross, Westerfield, \& Jordan, 2012). In this section, global and South African literature is reviewed with respect to dividend payout trends and the factors that influence dividend distribution decisions.

\section{Global dividend distributions}

The issue of corporate dividends dates back to the early 16th century in Holland and Great Britain when captains of sailing ships started selling financial claims to investors that entitled them to share in any proceeds of the voyages
(Al-Malkawi et al., 2010). Over time, corporate managers realised the importance of dividend payments in satisfying the expectations of shareholders. They often smoothed dividends in order to avoid the potential negative impact of dividend reductions on share prices (Al-Malkawi et al., 2010). During the 19th and early 20th centuries, dividend distributions increased and contributed significantly to shareholder investment returns (Baker \& Weigand, 2015; Straehl \& Ibbotson, 2017).

Today, however, global dividend distributions are in striking contrast to their historical levels. Since 1960, 81\% of Standard \& Poor's 500 (S\&P 500) index returns can be attributed to reinvested dividends and the power of compounding (Hartford Funds, 2016). However, dividend yields have declined over time. The median dividend yield for the period 1970-2015 was 4.33\%, with yields peaking in the 1980s and bottoming in the 2000s (Multpl, 2017).

Prior to the mid-1980s, companies in developed countries used cash dividends as the dominant means to distribute cash to shareholders. Since then, share repurchases have become popular as an alternative cash distribution method. As share repurchases grew, the proportion of profits paid out remained unchanged, suggesting that share repurchases supplanted dividends. The popularity of share repurchases can be attributed to their greater flexibility compared to a schedule of fixed quarterly or half-yearly dividends (Baker \& Weigand, 2015). In Europe and Asia, where dividends have played a bigger role than in America, companies have greatly increased the use of share repurchases (The Economist, 2014).

In addition to the flexibility advantages of share repurchases over dividends, taxes also account for the growing popularity of share repurchases relative to dividends. In many developed countries, dividend income has generally been taxed at higher rates than capital gains (Clayman, Fridson, \& Troughton, 2012). Therefore, in cases where taxes on dividends are higher than taxes on capital gains, investors may prefer capital gains from investments such as share repurchases to dividend payments.

\section{Dividend distributions in South Africa}

The South African dividend distribution context has undergone a radical change with the promulgation of the Companies Amendment Act 37 of 1999 (RSA, 1999), allowing companies to repurchase their shares. Since 01 July 1999, companies could return cash to shareholders not only through dividends but also by repurchasing shares. Section 90 of the Companies Amendment Act 37 of 1999 (RSA, 1999) stipulates that companies may distribute dividends provided liquidity (ability to pay debts as they fall due) and solvency (total assets after dividend distribution exceeds total liabilities) requirements were met. Section 46 of the new Companies Act 71 of 2008 (RSA, 2008), effective from 01 May 2011, strengthens the requirements pertaining to all types of distributions made by a company by including more stringent 
solvency and liquidity considerations prior to any distribution. The new Companies Act of 2008 (RSA, 2008) also stipulates that companies no longer need to have share premium accounts, and subsequently many companies have converted their share premium accounts to stated capital (and non-par shares).

In addition to the Companies Act changes, there were also several changes to the South African Income Tax Act with respect to dividend distribution taxation during the study period (1999-2014). In terms of sections 64D to $64 \mathrm{~N}$ of the Income Tax Act of 1962 (RSA, 1962), the main amendments entail the changing from a secondary tax on companies (STC) to a DWT regime, effective from 01 April 2012. Under the STC regime, a company distributing the dividend was taxed on dividend payments distributed from retained earnings, whereas dividends distributed from capital (namely, share premium and capitalised profits) generally did not attract STC (Wesson et al., 2015). The source of the distribution (i.e. retained earnings vs. share premium) was therefore important when ascertaining the tax effect of dividend payments (Wesson et al., 2015). As from 01 April 2012, STC was replaced by DWT in order to align South Africa with global distribution norms where dividend recipients, not the company paying dividends, were liable for the tax (SARS, 2017).

Prior to 01 April 2012, the tax implications for share repurchases and dividend payments by South African companies were generally similar: STC was levied on the distribution made (excluding the repayment of share capital and capitalised profits). There was, however, no STC levied on share repurchases made by subsidiaries (Wesson et al., 2015), nor on share repurchases by the holding company from their subsidiaries during the period prior to 01 October 2007 (Wesson \& Hamman, 2012). As from 01 April 2012 (under the DWT system), the tax treatment of share repurchases varies depending on the type of share repurchase used. There are two main types of share repurchases: (1) general (or open market) repurchases where a company buys back its own shares on the open market and (2) specific repurchases comprising pro rata tender offers and private offers to a specific group of shareholders (Wesson et al., 2015). Specific share repurchases are liable for DWT, whereas general share repurchases are DWT exempt (and taxable in terms of the capital gains tax regulations).

Dividend withholding tax was introduced in order to make South Africa an attractive investment destination by eliminating double taxation of corporates (under the STC regime) and increasing corporate accounting profits (SARS, 2017). Therefore, the South African income tax reforms were expected to positively impact the dividend distributions by JSE-listed industrial companies and not to fully mirror the declining dividend yields in developed countries.

South African studies incorporating share repurchases and dividends as a payout option found that dividends were still the preferred distribution method when compared to share repurchases for JSE-listed companies (excluding the basic resources and financial sectors) over the period 1999-2009 (Bester, 2008; Wesson et al., 2015). Aggregate dividend distributions were dominated by a few companies paying dividends every year. Dividends paid from profits were the favoured dividend type, representing $75 \%$ of total dividend payment value. Special dividends and dividends paid from share premium attributed only $13 \%$ and $11 \%$, respectively (Wesson et al., 2015). De Vries, Erasmus, Hamman and Wesson (2012) examined whether the introduction of specific share repurchases in 1999 resulted in changes in the dividend payout of JSE-listed companies for the period 1990-2009 and also found that companies that participated in specific share repurchases did not lower their dividend payments in order to repurchase shares. Consistent with the study by Firer, Gilbert and Maytham (2008), share repurchases were found to complement, rather than substitute, dividends.

Viviers et al. (2013) found that the number of JSE-listed companies paying dividends decreased substantially over the period 1977-2011. The results showed that young and small companies in the resources, financial and cyclical services sectors paid low dividends. Earnings and dividends proved to be highly concentrated among the larger listed companies, and significant differences were observed between sectors.

\section{Dividend payout theories}

The seminal paper of Lintner (1956) formed the foundation of contemporary theoretical attempts to explain the factors that corporate managers consider when making dividend payout decisions. Among other findings, the study concluded that dividend decisions are based on current earnings and the dividends of the previous year. In addition, Lintner (1956) found that managers first define dividend policies followed by other policies on issues such as investments, debts and cash holdings. Overall, Lintner (1956) found that American corporate managers view dividends as a reflection of profit growth sustainability. Lintner's paper was followed by the controversial work of Nobel Prize winners Miller and Modigliani (1961). They argued that in perfect markets without taxes and transaction costs, the payment of dividends does not have an impact on the value of a company and is therefore irrelevant. Shareholders, they observed, hold the same value whether a company pays dividends or not.

Contrary to the conclusions of Miller and Modigliani (1961), capital markets are neither frictionless nor perfectly efficient. To accommodate imperfect markets, researchers have since considered the role of taxes, asymmetric information, transaction costs, the desire to signal to the market the true worth of a company and the need to curb potential overinvestment by management. The work of Baker and Weigand (2015), presented in Table 1, provides s summary of the important dividend payout theories and explanations suggested by different researchers in response to Miller and Modigliani's (1961) conclusions. 
A striking feature of these theories and explanations is that the results are far from unanimous and elude any single theory. Convincing empirical support for the agency costs and asymmetric information explanations were found compared to the tax preference explanation (Baker \& Weigand, 2015). Baker and Weigand (2015) also found that recent theories involving behavioural considerations, company life cycle theory and catering theory provided useful insights despite producing some mixed results.

For the purpose of the present study, the effect of South African regulatory changes may warrant the taxes and clientele theory to be specifically relevant during the target period of this study.

TABLE 1: Major theories and explanations for paying dividends.

\begin{tabular}{|c|c|c|}
\hline Theories & Description and implications & Empirical evidence \\
\hline Bird-in-the-hand & $\begin{array}{l}\text { Gordon (1959) and Lintner (1962) argued } \\
\text { that investors prefer the certainty of } \\
\text { dividend payments to the possibility of } \\
\text { substantially higher future capital gains. } \\
\text { Therefore, corporates should keep dividend } \\
\text { payments high in order to maximise } \\
\text { shareholder value. }\end{array}$ & Mixed \\
\hline $\begin{array}{l}\text { Taxes and } \\
\text { clientele }\end{array}$ & $\begin{array}{l}\text { Investors prefer that companies retain cash } \\
\text { instead of paying dividends when tax rates } \\
\text { are higher on dividends than on long-term } \\
\text { capital gains (Black \& Scholes, 1974; Miller } \\
\& \text { Modigliani, 1961). If the tax rate on } \\
\text { dividends is higher than capital gains tax, } \\
\text { corporate managers should reduce dividend } \\
\text { payments in order to maximise the price of } \\
\text { shares. }\end{array}$ & Mixed \\
\hline
\end{tabular}

\begin{tabular}{|c|c|c|}
\hline $\begin{array}{l}\text { Asymmetric } \\
\text { information } \\
\text { (signalling) }\end{array}$ & $\begin{array}{l}\text { A company's announcements of an increase } \\
\text { (or decrease) in dividend payouts act as an } \\
\text { indicator of strong (or weak) future } \\
\text { prospects (Grullon, Michaely, \& } \\
\text { Swaminathan, 2002). Investors can infer } \\
\text { information about a company's future } \\
\text { earnings through the signal coming from } \\
\text { dividend announcements, both in terms of } \\
\text { the stability of and changes in dividends. } \\
\text { Thus, managers should be aware of market } \\
\text { reactions before they make dividend policy } \\
\text { decisions. }\end{array}$ & Mixed \\
\hline Agency costs & $\begin{array}{l}\text { Companies pay dividends to align the } \\
\text { interests and mitigate the agency problems } \\
\text { between managers and shareholders by } \\
\text { reducing the discretionary funds available } \\
\text { to managers (Jensen \& Meckling, 1976). } \\
\text { Holding excess cash balances increases } \\
\text { managers' degree of investment flexibility } \\
\text { that can be detrimental to shareholders if } \\
\text { the managers overindulge in expensive } \\
\text { investment projects or pricey executive } \\
\text { remuneration packages. }\end{array}$ & Mixed \\
\hline $\begin{array}{l}\text { Behavioural } \\
\text { explanations }\end{array}$ & $\begin{array}{l}\text { Investors prefer dividends for psychological } \\
\text { reasons relating to self-control, mental } \\
\text { accounting and hedonic editing. Age, } \\
\text { income and retirement status also influence } \\
\text { investor preference (Coleman, 2016). Older } \\
\text { and retired investors and low-income } \\
\text { households show increased demand for } \\
\text { dividends for purposes of consumption and } \\
\text { risk reduction. }\end{array}$ & Mixed \\
\hline $\begin{array}{l}\text { Company life } \\
\text { cycle theory }\end{array}$ & $\begin{array}{l}\text { The life cycle theory of dividends suggests } \\
\text { that as a company matures, its ability to } \\
\text { generate cash overtakes its ability to find } \\
\text { profitable investment opportunities } \\
\text { (Mueller, 1972). Therefore, the optimal } \\
\text { choice is for the company to distribute its } \\
\text { free cash flow to shareholders in the form } \\
\text { of dividends. }\end{array}$ & $\begin{array}{l}\text { Generally } \\
\text { supported }\end{array}$ \\
\hline Catering theory & $\begin{array}{l}\text { Prevailing investor demand for dividend } \\
\text { payers influences the decision to pay } \\
\text { dividends (Baker \& Wurgler, 2004). } \\
\text { Therefore, managers need to cater for } \\
\text { investor demand for dividends by paying } \\
\text { dividends when investors prefer } \\
\text { dividend-paying companies and by not } \\
\text { paying or reducing dividends when investors } \\
\text { prefer non-dividend-paying companies } \\
\text { (Baker \& Weigand, 2015). }\end{array}$ & Mixed \\
\hline
\end{tabular}

Source: Baker, H. K., \& Weigand, R. (2015). Corporate dividend policy revisited. Managerial Finance, 41(2), 126-144. https://doi.org/10.1108/MF-03-2014-0077

\section{Global empirical studies}

Several studies in both developed and emerging economies have tested empirical evidence of the factors that influence dividend distributions. Table 2 summarises notable global studies that reported significant factors that influence dividend payout decisions and their positive $(+)$ and negative (-) relationship with dividend payout.

The review of global studies below highlights the dividend payout conundrum, that is, the factors that influence

TABLE 2: Global studies on factors that influence dividend payout. Empirical study Country and significant dividend payout determinants Nizar Al-Malkawi Jordan: Insider shareholding (+), company size (+), company (2007)

Denis and Osobov United Kingdom, United States of America (USA), Canada, (2008) Germany, Japan and France: Company size (+), profitability (+) and retained earnings $(+)$

Denis and North America: Company size (+), profitability (+), growth

Stepanyan (2009) opportunities $(-)$, company maturity $(+)$, regulation $(+)$, leverage $(+)$, insider stock holdings (-) and institutional stock holdings (+)

Al-Kuwari (2009) Gulf Arab States/Gulf Cooperation Council (GCC): Government ownership (+), company size (+), profitability $(+)$ and debt $(-)$

Musa (2009) Nigeria: Previous dividend (-), current earnings (+) and cash flow (+)

Gill, Biger and USA:

Tibrewala (2010) Entire sample - profitability (+), corporate tax $(+)$, sales growth (-) and debt-to-equity ratio (-)

- Services industry - profitability $(+)$, sales growth (-) and debt-to-equity ratio (-)

- Manufacturing industry - profitability (-), corporate tax $(+)$ and market-to-book value (+)

Kapoor, Anil and India: Fast Moving Consumer Goods (FMCG) sector - cash flows Misra (2010) (-), investment opportunities (-), company size (+), profitability $(+)$ retained earnings $(-)$, capital expenditure $(-)$, systematic risk $(+)$, earnings variability $(+)$, financial risk $(+)$ and long-term solvency $(+)$

Moradi, Salehi and Iran: Profitability $(+)$, price earnings ratio $(-)$, beta rate $(-)$ and Honarmand (2010) debt ratio (-)

Imran (2011) Pakistan: Previous dividend per share (+), earnings per share (+), profitability $(+)$, cash flow $(-)$, sales growth $(+)$ and company size $(+)$

Hellström and Sweden:

Inagambaev (2012) - Large Cap companies - free cash flow (+), growth (-) and risk - $(-)$

- Medium Cap companies - free cash flow (-), leverage (-), risk $(-)$ and size $(+)$

Mehta (2012) United Arab Emirates: Profitability (+) and company size (+)

Adu-Boanyah,

Ayentimi and

Osei-Yaw (2013)

Nnadi, Wogboroma Twenty-nine stock exchanges in Africa: Profitability $(+)$, company and Kabel (2013) age (+), market capitalisation $(+)$ and financial leverage $(-)$

Uwuigbe (2013) Nigeria: Financial performance $(+)$, company size $(+)$ and board independence $(+)$

Abor and Fiador
(2013)

Sub-Saharan Africa:

- Other countries - board composition (+/-), board size (-) chief executive officer duality $(-)$, institutional shareholding

- South Africa - institutional shareholding (+)

Arko, Abor, Adjasi Sub-Saharan Africa:

and Amidu (2014) - Other countries - profitability (+), investment opportunities $(+)$, taxation $(-)$, leverage $(-)$, institutional shareholding $(-)$ and risk (-)

- South Africa - profitability (+), investment opportunities (+), company size $(+)$, leverage $(-)$ and risk (-)

Baah, Tawiah and Ghana: Return on equity $(+)$, profit after tax $(+)$ and company Opoku (2014)

Ahmed and Murtaza (2015)

Pakistan:

- Energy sector - earnings per share $(+)$ and leverage $(+)$

- Cement sector - liquidity (+)

- Oil sector - earnings per share (+)

Sugar sector - earnings per share (-), firm size $(+)$ and profitability $(+)$

Forti et al. (2015) Brazil: Company size $(+)$, returns $(+)$, market-to-book value $(+)$, liquidity $(+)$, control $(+)$, profit growth $(+)$, leverage $(-)$, corporate governance $(-)$, risk $(-)$ and information asymmetry $(-)$

Note: Please see the full reference list of the article, Nyere, L., \& Wesson, N. (2019). Factors Note: Please see the full reference list of the article, Nyere, L., \& Wesson, N. (2019). Factors
influencing dividend payout decisions: Evidence from South Africa. South African Journal of Business Management 50(1), a1302. https://doi.org/10.4102/sajbm.v50i1.1302, for more information. 
dividend payout are inconclusive and vary considerably between countries and within different sectors of the same country. However, some factors such as profitability, current earnings, company size and cash flows show strong correlation with dividend payout decisions.

\section{South African studies}

In studying dividend payout decisions, researchers typically rely on two complementary approaches, that is, using statistical analysis of published financial data to test various hypotheses about dividend policy and using survey methodology to obtain primary data about dividend policy from corporate managers (Baker \& Weigand, 2015). In South Africa, two comprehensive survey studies on factors influencing dividend payments were completed by Firer et al. (2008) and Sibanda (2016). A review of South African literature on the determinants of dividend payout since the introduction of share repurchases and DWT in 1999 and 2012, respectively, as well as the effect of the 2008 financial crisis, showed limited evidence of studies based on published financial data, one of the objectives the present study satisfied.

Firer et al. (2008) and Sibanda (2016) conducted comprehensive surveys to establish the key factors that JSElisted corporate executives consider when making dividend payout decisions. In both studies, the corporate executives indicated stability of future earnings, availability of good investment opportunities, availability of cash or liquid assets and maintaining smooth dividend payout as key considerations when making dividend payout decisions. Firer et al. (2008) and Sibanda (2016) reported that 74\% and $67 \%$ of their study participants, respectively, agreed that the consequences of reducing dividends were severe, stressing the importance of dividend smoothing. Sibanda (2016) observed that a temporary change in earnings was a less important consideration. With respect to dividend taxation, Firer et al. (2008) found liability for corporate tax (STC) and floatation costs associated with issuing additional equity capital as less important considerations. Sixty-one per cent of respondents surveyed by Sibanda (2016) indicated the importance of dividend payout decisions relative to investing and financing decisions.

Studies using statistical analysis of published financial data include the study of Arko et al. (2014) that examined the determinants of the dividend decisions of companies in sub-Saharan Africa over the period 1997-2007. The sample set was drawn from the financial services, mining, manufacturing, agriculture, food and confectionery and services sectors. The study found that South African companies set dividends to reflect improvements in their fundamental financial records (higher profitability levels, higher growth opportunities and larger company size), while dividend omissions and reductions reflected negative company fundamentals (increased risk, both earnings volatility and financial risk). In addition, South African companies maintained stable dividend distributions in response to both an active investor community and an information-efficient market.

Mans-Kemp (2015) and Abor and Fiador (2013) investigated the relationship between corporate governance and dividend payout ratios (DPRs) of JSE-listed companies. Mans-Kemp covered the period 2002-2010, while Abor and Fiador examined sub-Saharan African companies over the period 1997-2006. Mans-Kemp (2015) found that companies exhibiting sound corporate governance compliance typically pay high dividends, and the mean annual corporate governance scores and dividend payout of the companies increased, except in 2008 and 2009, probably owing to the global financial crisis. Abor and Fiador (2013) found that only institutional shareholding (as a proxy for corporate governance) showed a significant positive relationship with dividend payout in South Africa during the period 1997-2006.

Sibanda (2014) analysed the appropriateness of Lintner's (1956) dividend smoothing model using a sample of 45 JSElisted companies over the period 1995-2011. Despite a reduction in the number of dividend-paying companies, the results showed that JSE-listed companies tend to smooth their dividends over time. This conclusion was in contrast to an earlier study by Wolmarans (2003), who concluded that Lintner's (1956) model was not an entirely appropriate fit for explaining South African dividend payments. However, Wolmarans (2003) used a very small sample size owing to data limitations, and this could have influenced the results.

Vermeulen and Smit (2011) found that, contrary to conventional wisdom, South African companies with high DPRs tend to realise stronger future earnings growth. The study covered the period 1973-2009 and included companies from 10 industries: oil and gas, basic materials, industrial, consumer goods, healthcare, consumer services, telecommunications, utilities, financial and technology. Mtshali (2016), however, found a strong positive relationship between changes in dividends and current earnings, but no significant relationship with future earnings. The study covered the period 2003-2013 and analysed 226 dividendpaying companies. Consistent with Lintner's (1956) model on dividend policy, companies that had increased their dividends were found less likely to experience a reduction in earnings, as opposed to the no-change or dividenddecrease groups.

Wesson, Smit, Kidd and Hamman (2018) incorporated share repurchase and dividend behaviour of JSE-listed companies (excluding the basic resources and financial sectors) over the period 1999-2009 and investigated the factors influencing a company's choice between open market share repurchases and special dividend payments. Shareholder heterogeneity, the size of the distribution and the level of company undervaluation were significant determinants affecting the payout choice in South Africa. Smaller companies, with 
fewer shareholders and public investors, favoured open market share repurchases over special dividends. Higher directors' ownership and debt levels were associated with open market share repurchases and companies already paying high dividends tended to favour special dividends.

\section{Study variables and hypotheses}

The choice of company-specific variables investigated in the present study is motivated by global and South African literature, as well as the availability of reliable JSE-listed industrial sector data. Table 3 presents a summary of the factors used in this study and their expected relationship with DPR, the dependent variable.

\section{Company size}

Large and mature companies tend to pay higher dividends than companies that are growing and consolidating in the market (Denis \& Stepanyan, 2009; Forti et al., 2015; Nizar AlMalkawi, 2007). Unlike large companies, small companies usually face relatively abundant investment opportunities with limited resources and they rely heavily on internally generated funds to fund capital requirements (DeAngelo, DeAngelo, \& Stulz, 2006). Two measures were used in the present study as proxies for company size, that is, numerical variable market capitalisation (SIZE) and a categorical variable JSE index classification (CLS). Therefore, SIZE and CLS variables were expected to have a positive relationship with DPR in this study.

\section{Company risk}

This study employed two measures of business risk: company systemic risk (BETA) and debt to equity (LVRG). Global empirical evidence on the relationship between company risk and dividend payout has been found to be inconclusive. Some studies found that companies facing greater risks because of high debt levels are more reluctant to pay high dividends because of future uncertainty of cash flows (Forti et al., 2015; Hellström \& Inagambaev, 2012; Makka, 2014). In order to minimise the risk of failing to service their debts or liquidation, companies with high debt levels tend to lower their dividend payout. In contrast, other studies found a positive relationship between dividend payout and the level of debt (Denis \& Stepanyan, 2009). This is particularly true for large companies because they have better access to capital markets as they are usually able to provide collateral and can afford to pay higher dividends (Adu-Boanyah et al., 2013; Viviers et al., 2013). Therefore, it was expected that DPR could be either positively or negatively related to the LVRG variable and negatively related to the BETA variable.

\section{Investment opportunities}

The retention of internally generated funds is preferable to issuing shares mainly because of flotation costs associated with raising external capital. Companies investing in numerous projects typically retain profits to finance investments and are less likely to pay dividends (Forti et al., 2015; Kapoor et al., 2010; Nnadi et al., 2013). This implied that

TABLE 3: Summary of study variables.

\begin{tabular}{|c|c|c|c|c|}
\hline Variable & Proxy for & Operational definition & Data source & Expected relationship \\
\hline \multicolumn{5}{|l|}{ Dependent variable } \\
\hline Dividend payout ratio (DPR) & Dividend payout & $\begin{array}{l}\text { (Dividends paid/shares in issue weighted average)/ } \\
\text { (profit attributable to ordinary shareholders/shares } \\
\text { in issue weighted average) }\end{array}$ & $\begin{array}{l}\text { Dividends data extracted from the annual } \\
\text { financial reports, IRESS profit attributable } \\
\text { to ordinary shareholders and shares in } \\
\text { issue weighted average }\end{array}$ & $n / a$ \\
\hline \multicolumn{5}{|c|}{ Independent numerical variables } \\
\hline Market capitalisation (SIZE) & Company size & $\begin{array}{l}\text { Natural logarithm of the company's JSE market } \\
\text { capitalisation }\end{array}$ & IRESS market capitalisation & $(+)$ \\
\hline Systemic risk (BETA) & Company risk & Company systemic risk measured by BETA & IRESS BETA weekly leveraged & $(-)$ \\
\hline Debt-equity ratio (LVRG) & Company risk & $\begin{array}{l}\text { (Long-term liabilities + current liabilities)/(ordinary } \\
\text { shareholders interest + preference shares + outside } \\
\text { shareholders' interest + directors and shareholder loans } \\
\text { - intangible assets) }\end{array}$ & IRESS debt/equity ratio & $(+/-)$ \\
\hline Total assets growth (INVEST) & Investment & $\begin{array}{l}\text { (Current year total assets [excluding intangible assets] } \\
\text { - previous year total assets [excluding intangible assets])/ } \\
\text { (previous year total assets [excluding intangible assets]) }\end{array}$ & IRESS total assets ratio & $(-)$ \\
\hline Sales growth (GRWTH) & Growth & $\begin{array}{l}\text { (Current year sales revenue }- \text { previous year sales } \\
\text { revenue)/(previous year sales revenue) }\end{array}$ & IRESS net turnover ratio & $(-)$ \\
\hline Earnings ratio (PROF) & Profitability & $\begin{array}{l}\text { Accounting profits distributed to shareholders, that is } \\
\text { (investment income + operating profit + interest received } \\
+ \text { associate companies)/(total assets) }\end{array}$ & IRESS return on assets ratio & $(+)$ \\
\hline Cash flows (FCF) & Free cash flow & $\begin{array}{l}\text { Cash flow from operations more than capital expenditure } \\
\text { requirements disclosed in the cash flow statement, that is } \\
\text { (net cash from total activities)/(total capital employed) }\end{array}$ & $\begin{array}{l}\text { IRESS cash flow (Ncta) to capital } \\
\text { investments ratio }\end{array}$ & $(+)$ \\
\hline Net assets ratio (SOLV) & Liquidity & Total assets (excluding intangible assets)/(total liabilities) & $\begin{array}{l}\text { IRESS total assets (excluding intangible } \\
\text { assets) to total liabilities }\end{array}$ & $(+)$ \\
\hline Current ratio (LIQD) & Liquidity & (Total current assets)/(total current liabilities) & IRESS current ratio & $(+)$ \\
\hline \multicolumn{5}{|c|}{ Independent categorical variables } \\
\hline JSE index (CLS) & Company size & JSE Index classification & $\begin{array}{l}\text { Large companies comprised JSE Top } 40 \\
\text { and Mid Cap indices and small companies } \\
\text { comprised Small Cap and Fledgling indices }\end{array}$ & $(+)$ \\
\hline ICB sector (SECT) & Company sector & ICB industry classification of listed companies & Bloomberg ICB sector data & - \\
\hline \multicolumn{5}{|l|}{ Independent binary variable } \\
\hline Paid dividend (PDIV) & Paid dividend & $\begin{array}{l}\text { Binary variable to identify the company-years when } \\
\text { dividends were paid (1) or not paid (0) }\end{array}$ & $\begin{array}{l}\text { Derived from dividend payout variable - if } \\
\text { a company paid dividends (1) or not (0) }\end{array}$ & - \\
\hline
\end{tabular}

FCF, free cash flow; ICB, International Classification Board; JSE, Johannesburg Stock Exchange; n/a, not applicable; IRESS, Integrated Real-time Electronic Securities System. 
an inverse relationship was expected between the INVEST and DPR variables.

\section{Sales growth}

Some global studies have concluded that a negative relationship exists between the sales growth rate of a company and the DPR (Gill et al., 2010), while other studies have found a positive relationship (Imran, 2011). Despite these contradictory results, companies with higher sales growth generally have working capital requirements more than cash flows from operations. Consequently, such companies retain current earnings in order to support future sales growth. In contrast, profitable companies with slow sales growth generally pay higher dividends to minimise potential agency cost problems when corporate managers overindulge in expensive investment projects (Arko et al., 2014; Jensen \& Meckling, 1976). Therefore, a negative relationship was expected between sales growth (GRWTH) and dividend payout (DPR) in this study.

\section{Profitability}

Corporate profitability has been found to be a significant and consistent determinant of dividend payout (Firer et al., 2008; Forti et al., 2015; Kapoor et al., 2010). In rare instances, profitability was found to be insignificant (Hellström \& Inagambaev, 2012). The present study employed return on assets (ROA) as a proxy for profitability because ROA captures the accounting profits that are available for distribution to shareholders (Fama \& French, 2001). Companies with higher profitability can continue to finance growth while still making consistent payments to shareholders (Forti et al., 2015). A positive relationship was thus expected between the PROF and DPR variables.

\section{Free cash flows}

A company may be profitable and still be cash poor because cash, not profit, pays dividends. Therefore, it is expected that free cash flow has a direct impact on a company's ability to pay dividends. Profitable companies with more stable earnings can expect larger free cash flows and thus pay larger dividends (Hellström \& Inagambaev, 2012; Musa, 2009). Consequently, FCF was expected to be positively related with DPR in this study.

\section{Liquidity}

Legal restrictions may limit the amount of dividends that a company pays. The liquidity and solvency requirements specified in South African legislation are pertinent. Section 46 of the new Companies Act of 2008 (RSA, 2008), effective from 01 May 2011, strengthened the requirements pertaining to all types of distributions made by a company by including more stringent solvency and liquidity considerations prior to cash distributions. Therefore, net assets (SOLV) and current ratio (LIQD) constitute important determinants of dividend payout (Forti et al., 2015) and were expected to be positively related with DPR.

\section{Additional variables}

The following additional variables were included in order to perform the statistical analyses:

Paid dividend (PDIV): This is a binary variable used to identify the company-years when dividends were paid (1) or not paid (0).

International Classification Board sector (SECT): For the purposes of company sector analysis, companies were classified using International Classification Board (ICB) data extracted from Bloomberg by the middle of each calendar year. The JSE classifies all listed companies into three South African sectors, namely, resources, financial and industrial (JSE, 2017). In order to identify industrial sector companies, the following mapping of the South African sector classification to the global ICB methodology was applied in the present study:

- Resources sector comprised ICB oil and gas producers (0530) and mining (1770) sectors.

- Financial sector comprised ICB financial (8000) industry.

- Industrial sector comprised companies in the remaining ICB sectors - therefore, comprising the industrial (2000), consumer goods (3000), healthcare (4000), consumer services (5000), telecommunications (6000), utilities (7000) and technology (9000) industries.

Based on the expected relationship of the identified variables with DPR (Table 3) and the literature pertaining to dividend payout behaviour in South Africa, the following hypotheses were formulated:

H1: The dividend payout of JSE-listed industrial companies increased from the pre-recession (1999-2007) to the postrecession (2008-2014) period.

H2: The dividend payout of JSE-listed industrial companies is positively affected by company size (SIZE and CLS), profitability (PROF), free cash flows (FCF) and liquidity (SOLV and LIQD); negatively affected by company systemic risk (BETA), investment opportunities (INVEST) and sales growth (GRWTH); and either positively or negatively affected by company risk measured as debt to equity (LVRG).

\section{Research method}

The research method of this study mirrors the methodology applied in Wesson et al.'s (2015) study in that it is based on data extracted from published annual financial reports. The remainder of the section covers the research population, data sources and data collection methodology and the data analysis methods used.

\section{Research population}

Consistent with Wesson et al.'s (2015) study, the following categories of JSE-listed companies formed the population for the reporting periods from 01 July 1999 to the 2014 year-ends of the companies:

- companies with listed ordinary and/or N-class shares 
- companies with the JSE as their primary listing

- companies listed on the JSE main board, except companies in the resources and financial sectors.

Companies in the resources sector generally follow commodity prices rather than company-specific factors, whereas the financial sector companies are highly regulated and have capital structures with high, but acceptable, debt levels (Bester, 2008). Given these sector-specific differences, the factors influencing the dividend payout of industrial sector companies were likely to be different from those of the resources and financial sectors.

Both dividend-paying and non-dividend-paying companies formed part of the population in order to eliminate selection bias or systematic exclusion of part of the population. Companies may find it optimal to reduce or pay no dividends at different times in response to internal or external factors. Excluding non-dividend-paying companies from empirical analysis would result in inconsistent estimates of the population parameters (Al-Malkawi et al.,2010). Additionally, the population included all industrial companies listed and/ or delisted during the study period. Excluding delisted companies could create survivorship bias that might influence the results of the study as only companies successful enough to survive are analysed.

To ensure completeness of the population, the companies included in the population were verified using the JSE Profile Stock Exchange Handbooks from 01 July 1999 to December 2014, taking note of name changes, new listings and delistings, as well as movements between sectors (JSE, 1999-2014). The study period (1999-2014) was chosen to coincide with the amendment of the Companies Act in 1999 (RSA, 1999) to allow companies to repurchase their shares as an alternative cash distribution method. The period was long enough to average out results or smooth over any possible outliers, thus providing opportunities for rigorous analysis of differences in dividend payouts between pre-recession (1999-2007) and post-recession (2008-2014) periods across different sectors (Makka, 2014).

To better understand the dividend distribution trends, the population was classified into large (Top 40 and Mid Cap indices) and small (Small Cap and Fledgling indices) categories using the JSE index classification variable (CLS). Prior to the introduction of JSE index classifications in 2002, companies were classified using the all share index (ALSI) market capitalisation. If a company was in the top 100 companies (proxy for Top 40 and Mid Cap), then it was classified as a large company; otherwise, it was classified as a small company.

A total of 391 companies formed part of the population, resulting in 3194 company-years over the study period. Of the 391 companies, $66 \%$ (258 companies) paid dividends in at least 1 year during the study period and $34 \%$ (133 companies) did not pay dividends. The split between dividend-paying and non-dividend-paying companies was 1867 (58\%) and 1327 (42\%) company-years, respectively.

\section{Data sources and collection}

This study used dividend data extracted from published annual financial reports. The comprehensive dividend database created by Wesson et al. (2015), covering 1999-2009, formed the basis of the study. Additional dividend data for the remainder of the study period were obtained from annual financial reports (retrieved via IRESS: Product Library) using the same data collection method employed by Wesson et al. (2015). The dividend data collected were reconciled and verified using the directors' report, statement of cash flows, statement of changes in equity and dividend notes.

Dividends paid at company level were extracted from published annual financial reports and the necessary verification procedures were applied to ensure that dividend data comprised prior-year final dividend and current-year interim dividend paid in the current year, and to correctly distinguish between dividends paid from profits, share premium distributions and special dividends (Wesson et al., 2015).

To establish statistical differences between periods and real dividend payout trends, all distributions from 2000 to 2014 were represented in terms of 1999 prices using deflation factors calculated from inflation values published by Statistics South Africa (2017).

The IRESS database was used to extract data other than dividend data (Table 3). Where data errors were identified, published annual financial statements (retrieved via IRESS: Product Library) were used to verify the data.

\section{Data analysis methods}

Descriptive statistics and a fixed-effects panel regression analysis were used to explore the dividend payout trends and the explanatory power of the nine numerical independent variables. Data distributions for the dependent variable (DPR) and the independent variables were created and analysed. All variables, except market capitalisation (SIZE), which was represented as a natural logarithm, were adjusted (winsorised) by replacing outliers with a value representing three times the calculated standard deviation plus the calculated mean. By taking the natural logarithm of market capitalisation, the impact level of outliers was eliminated (Analysights, 2010).

To identify the most appropriate regression analysis model, a fixed-effects test was completed. Ordinary least squares (OLS) regression was found to be appropriate. This was followed by a time-effect test to determine a one-way or twoway model, and a Hausman test for random effects to choose between a fixed- and random-effects model. Owing to the unbalanced nature of the data (companies do not have the same number of time points), a random-effects model could 
not be fitted. Consequently, the data were analysed using a fixed-effects model.

Regression assumptions of heteroscedasticity, normality and multicollinearity were tested by conducting a redundancy analysis and Breusch-Pagan Lagrange multiplier. The results of the redundancy analysis found no correlation between the independent variables when the tolerance cut-off level was set at 0.4. The redundancy results were SIZE (0.48), BETA (0.91), LVRG (0.54), INVEST (0.63), GRWTH (0.65), PROF (0.72), FCF (0.95), SOLV (0.46) and LIQD (0.46). Where the Breusch-Pagan test indicated conditional heteroscedasticity, the original regression was adjusted for heteroscedasticity.

A fixed-effects panel regression analysis was conducted for the dependent (DPR) and the independent variables. The panel regression was completed for different time periods, that is, pre-recession (1999-2007), post-recession (2008-2014) and full period (1999-2014). Further analysis was conducted using the categorical variables JSE Index (CLS) and ICB sector (SECT) in order to understand the difference between dividend-paying and non-dividend-paying companies.

The regression coefficients were interpreted based on their sign, and not in absolute terms. The significance of coefficients generated by the fixed-effects panel regression was evaluated using calculated probability ( $p$-value) for each coefficient. The $5 \%(p<0.05)$ significance level was used as a guideline to determine significant and insignificant relationships.

\section{Ethical consideration}

Ethical clearance to conduct the study was obtained from the Stellenbosch University Business School (Ethical clearance number: SU-HSD-003530).

\section{Research results \\ Descriptive statistics}

Over the study period (1999-2014), the total aggregate nominal dividend distribution was R567.23 billion. Dividends paid increased by a compound annual growth rate of $27.86 \%$, from R2.2bn in 1999 to R87.81bn in 2014. Consistent with the observations made by Wesson et al. (2015) and Bester (2008), dividends paid from profits were the favoured dividend type, representing $92.3 \%$ of the total dividends value, and grew over the study period. It appears that the global financial crisis of 2008 had a lagged effect on dividends (Figure 1): there was a reduction in dividends paid in 2010 before the increasing trend continued in 2011.

Distributions from share premium represented a small proportion of the total dividend payments $(7.7 \%)$. The share premium distributions showed a steady growth from 1999 through to 2007 before slowing down during 2008 and 2009. In 2010, distributions from share premium increased, followed by a gradual decrease during the remainder of the study period. The decrease in share premium distributions after 2010 was expected in line with the regulatory changes affecting the availability of share premium accounts (many companies converted their par value shares and share premium accounts to a stated capital account as from 01 May 2011) and the utilisation thereof when paying dividends (share premium distributions no longer had tax consequences under the DWT regime, from 01 April 2012, as opposed to the STC regime). From Figure 1, the growth in dividend payouts from 2012 to 2014 suggests that the change from STC to DWT positively influenced dividend distributions by aligning the South African regulatory environment with global practice. Consistent with the theory of taxes and clienteles (Black \& Scholes, 1974), the prevailing dividend taxation system under the DWT regime favoured dividend payments.

The number of both dividend-paying and non-dividendpaying categories was dominated by small companies. However, the number of small companies paying dividends decreased over the study period, possibly because of the growing adoption of share repurchases as a flexible distribution method (Wesson et al., 2018) or because of the fact that smaller companies face investment opportunities with limited free cash flows (DeAngelo et al., 2006). Despite the large number of small companies in the dividend-paying population, it was the large companies that contributed the largest proportion of dividend distributions (Figure 2). The annual inflation-adjusted dividend distributions were concentrated among large companies, consistent with

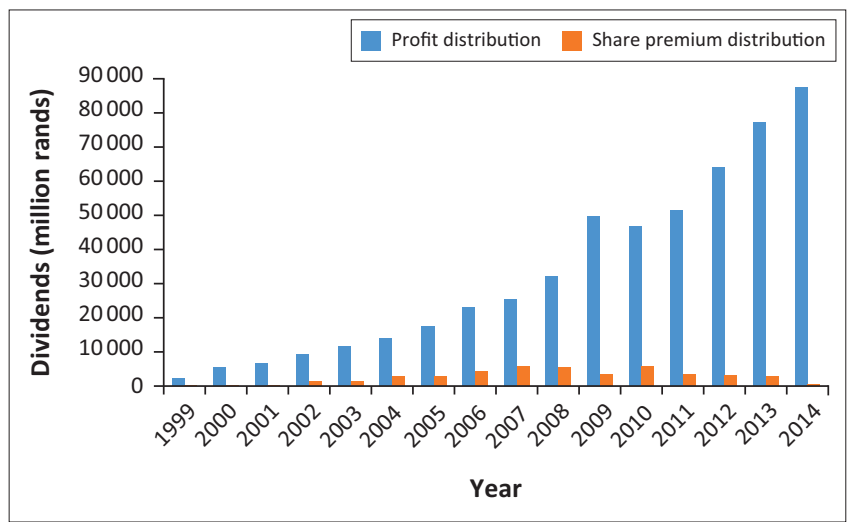

FIGURE 1: Dividend payout trends in Johannesburg Stock Exchange-listed companies.

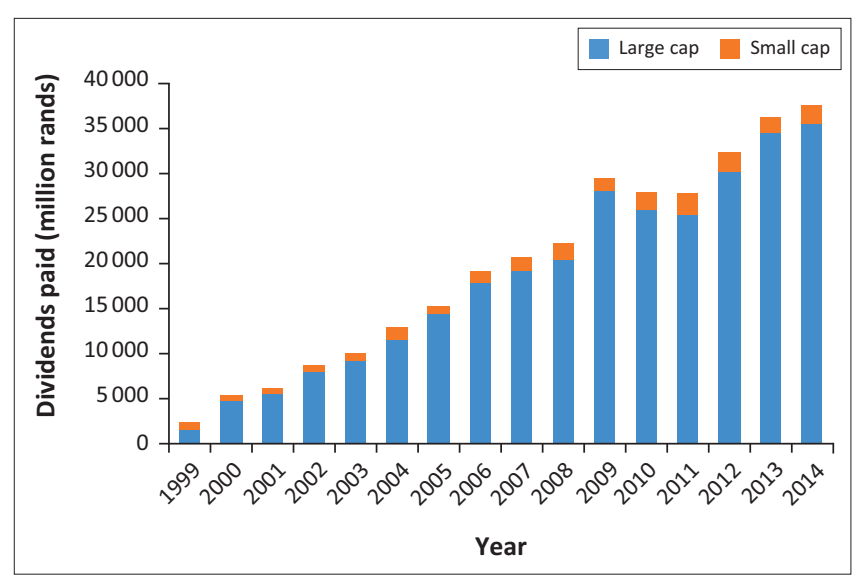

FIGURE 2: Real dividends paid by company size. 
previous observations by Viviers et al. (2013) and global observations (Denis \& Osobov, 2008). Significant statistical differences in mean real dividends paid by large and small companies were found at $1 \%$ significance level $(p<0.01)$, that is, large companies paid more dividends compared to small companies.

When comparing different ICB categories (based on the SECT variable), the study found a growing propensity to pay dividends by companies in the telecommunications, industrial, consumer services and healthcare sectors (Figure 3). Dividend payouts by ICB industrial companies account for the temporary post-recession decline in real dividends. The impact of the decline was countered by solid dividend payout growth from the telecommunications companies. By inspecting the source data, it was found that the number of telecommunications companies paying dividends increased from two in 2000 to a maximum of six between 2008 and 2012 before dropping to four in 2014 Therefore, the increase in aggregate dividends was mainly a result of the growth in real dividends paid by companies in the telecommunications sector.

Based on the total number of companies (391) that formed part of the population over the study period (1999-2014), the number of companies per ICB sector (SECT) included industrial (146), consumer services (96), consumer goods (70), technology (50), healthcare (18), telecommunications (9) and utilities (2). For the purposes of conducting variance analysis per ICB sector, the healthcare, telecommunications and utilities sectors were excluded owing to their smaller number of companies. A significant increase in mean real dividends was found for all ICB sectors at 5\% level of significance $(p<0.05)$ from pre-recession $(1999-2007)$ to postrecession (2008-2014) levels. In addition, the probability to pay dividends was highest for consumer services companies, followed by consumer goods, industrial and technology companies in descending order. Thus, clientele-seeking dividend returns are better invested in JSE-listed companies to tap into the growing dividend payouts across all ICB sectors.

Table 4 shows the mean, median and standard deviation of annual dividend payments for the full period (1999-2014), pre-recession period (1999-2007) and post-recession period (2008-2014). The mean DPR for the full period was 0.21 , while the median was 0.13 , suggesting a few large dividend distributions were made by JSE-listed industrial companies. When comparing the pre-recession and post-recession periods, the average DPR increased from 0.19 to 0.35 . This increase in dividend payout corresponds with an increase in company size (SIZE), leverage (LVG) and profitability (PROF). However, company risk (BETA), investment opportunities (INVEST), sales growth (GRWTH), free cash flow (FCF), solvency (SOLV) and liquidity (LIQD) decreased over the same period. This indicates that JSE-listed industrial companies experienced significant dividend distribution growth in line with higher market capitalisation, leverage and profitability; and lower investment opportunities, sales growth, free cash flows, solvency and liquidity. These attributes suggest the use of dividend payouts to minimise the agency problem associated with availability of discretionary funds to managers (Jensen \& Meckling, 1976).

\section{Inferential statistics Variance estimation, precision and comparison}

To understand the difference between companies that paid dividends and those that did not pay dividends (based on the PDIV variable), a variable-level analysis was conducted to

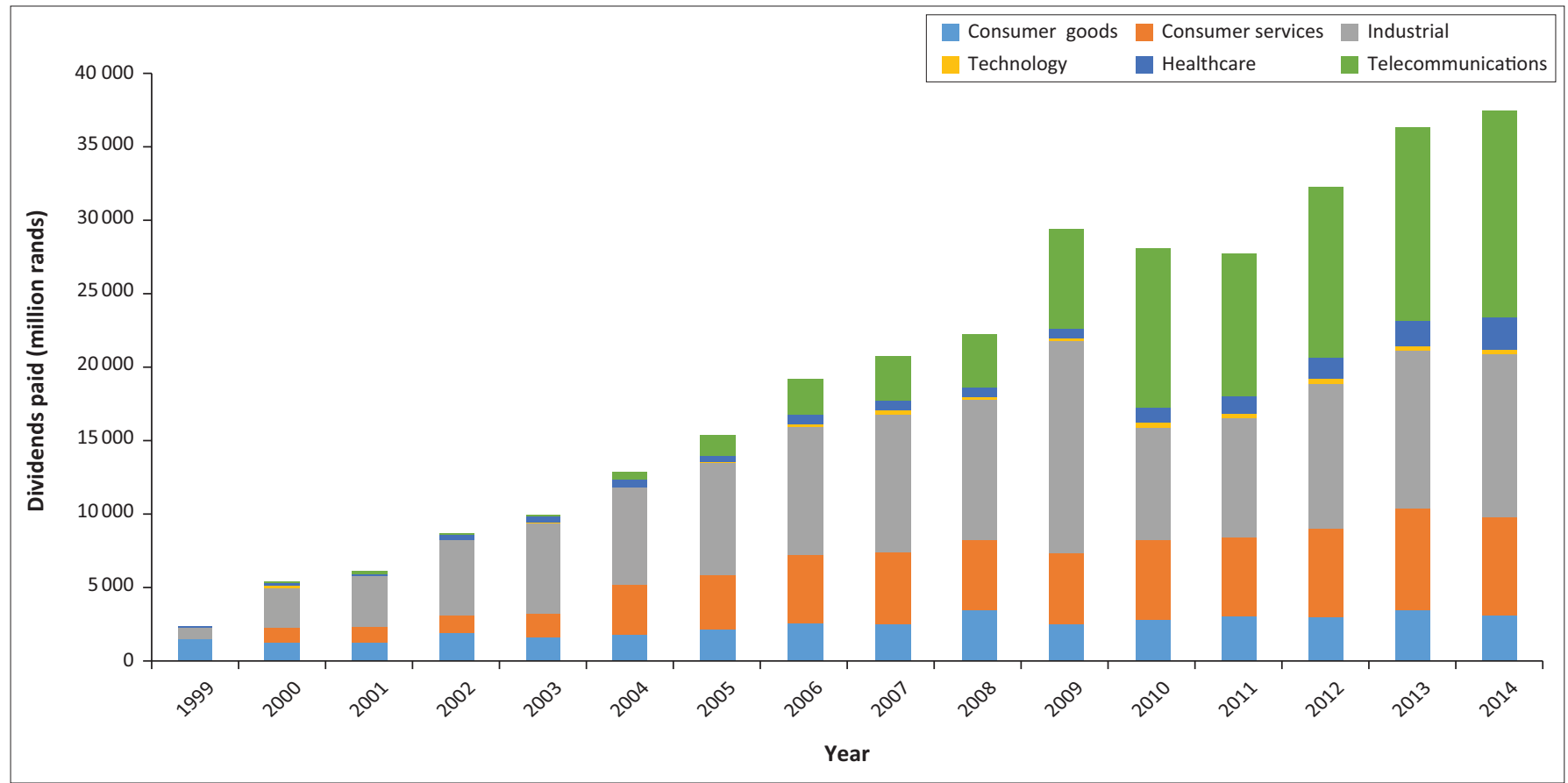

FIGURE 3: Real dividends paid per International Classification Board sector. 
TABLE 4: Descriptive statistics of study variables.

\begin{tabular}{|c|c|c|c|c|}
\hline Variable & Period & Median & Mean & Standard deviation \\
\hline \multirow[t]{3}{*}{ DPR } & Full period & 0.13 & 0.21 & 0.29 \\
\hline & Pre-recession & 0.03 & 0.19 & 0.73 \\
\hline & Post-recession & 0.21 & 0.35 & 2.81 \\
\hline \multirow[t]{3}{*}{ SIZE } & Full period & 19.90 & 19.87 & 2.54 \\
\hline & Pre-recession & 19.47 & 19.36 & 2.52 \\
\hline & Post-recession & 20.41 & 20.54 & 2.41 \\
\hline \multirow[t]{3}{*}{ BETA } & Full period & 0.37 & 0.40 & 0.40 \\
\hline & Pre-recession & 0.41 & 0.47 & 0.89 \\
\hline & Post-recession & 0.33 & 0.31 & 0.58 \\
\hline \multirow[t]{3}{*}{ LVRG } & Full period & 31.50 & 98.83 & 145.11 \\
\hline & Pre-recession & 27.00 & 124.98 & 315.33 \\
\hline & Post-recession & 40.10 & 197.56 & 432.93 \\
\hline \multirow[t]{3}{*}{ INVEST } & Full period & 9.78 & 11.81 & 26.88 \\
\hline & Pre-recession & 10.45 & 48.70 & 607.79 \\
\hline & Post-recession & 8.93 & 20.58 & 120.71 \\
\hline \multirow[t]{3}{*}{ GRWTH } & Full period & 11.18 & 12.89 & 26.72 \\
\hline & Pre-recession & 12.45 & 36.66 & 330.85 \\
\hline & Post-recession & 10.18 & 28.40 & 250.06 \\
\hline \multirow[t]{3}{*}{ PROF } & Full period & 10.61 & 9.49 & 16.36 \\
\hline & Pre-recession & 10.30 & -11.59 & 430.19 \\
\hline & Post-recession & 11.08 & 638.49 & 23435.00 \\
\hline \multirow[t]{3}{*}{ FCF } & Full period & 10.91 & 153.11 & 347.77 \\
\hline & Pre-recession & 123.58 & -7626.39 & 321714.01 \\
\hline & Post-recession & 119.45 & -20956.30 & 601566.01 \\
\hline \multirow[t]{3}{*}{ SOLV } & Full period & 1.74 & 2.05 & 0.98 \\
\hline & Pre-recession & 7.78 & 32.56 & 470.86 \\
\hline & Post-recession & 1.69 & 9.96 & 108.84 \\
\hline \multirow[t]{3}{*}{ LIQD } & Full period & 1.44 & 1.71 & 0.93 \\
\hline & Pre-recession & 1.46 & 3.21 & 26.43 \\
\hline & Post-recession & 1.42 & 1.95 & 2.79 \\
\hline
\end{tabular}

DPR, dividend payout ratio; SIZE, company size; BETA, company systemic risk; LVRG, debt-equity ratio; INVEST, investment opportunities; GRWTH, sales growth; PROF, profitability; FCF, free cash flow; SOLV, net assets ratio; LIQD, current ratio.

TABLE 5: Results of variance estimation, precision and comparison

\begin{tabular}{lrrl}
\hline Independent variable & $\begin{array}{c}\text { Non-dividend payers } \\
\text { (mean) }\end{array}$ & $\begin{array}{c}\text { Dividend payers } \\
\text { (mean) }\end{array}$ & $\boldsymbol{p}$ \\
\hline SIZE & 18.21 & 21.06 & $0.00^{* *}$ \\
BETA & 0.39 & 0.41 & $0.00^{* *}$ \\
LVRG & 13.68 & 159.86 & $0.00^{* *}$ \\
\hline INVEST & 7.84 & 14.44 & $0.00^{* *}$ \\
GRWTH & 10.70 & 14.38 & $0.01^{*}$ \\
PROF & 1.83 & 14.92 & $0.00^{* *}$ \\
FCF & 114.50 & 180.31 & $0.01^{*}$ \\
SOLV & 1.86 & 2.19 & $0.00^{* *}$ \\
LIQD & 1.58 & 1.80 & $0.00^{* *}$ \\
\hline
\end{tabular}

SIZE, company size; BETA, company systemic risk; LVRG, debt-equity ratio; INVEST, investment opportunities; GRWTH, sales growth; PROF, profitability; FCF, free cash flow; SOLV, net assets ratio; LIQD, current ratio.

$*, p<0.05 ; * *, p<0.01$.

test the difference between the mean values of each variable. The variance estimation, precision and comparison (VEPAC) method was used because it provides comprehensive estimates of variance while comparing fixed effects associated with multiple sources of variation (StatSoft Southern Africa, 2013). Table 5 presents the VEPAC results. The results show that all variables, apart from sales growth (GRWTH) and free cash flow $(\mathrm{FCF})$, were statistically significant at the $1 \%$ significance level $(p<0.01)$. The results for the GRWTH and FCF variables were significant at the $5 \%$ significance level $(p<0.05)$. Therefore, it can be inferred that dividend-paying JSE-listed industrial companies were large companies (SIZE) characterised by higher risk (BETA and LVRG), investment opportunities (INVEST), sales growth (GRWTH), profitability (PROF), free cash flows (FCF) and liquidity (SOLV and LIQD) relative to non-dividend-paying companies.

\section{Fixed-effects panel regression results}

In testing the hypotheses of the study, the dividend payout of JSE-listed industrial companies in the pre-recession (19992007) and post-recession periods (2008-2014) was firstly compared. A statistically significant increase in mean dividend payout from 0.46 (in the pre-recession period) to 0.53 (in the post-recession period) at $1 \%$ significance level $(p<0.01)$ was found. Therefore, Hypothesis 1 (H1) is accepted and confirms that the dividend payouts of JSE-listed industrial companies indicate a strong growth over the study period. It can be inferred that dividend payments in South Africa are growing in contrast to global observations of declining dividend yields. The results provide support for the theory of taxes and clienteles, in line with the expectation that the DWT regime (effective from 01 April 2012 in South Africa) favoured dividend payments over share repurchases in this country.

Secondly, further analysis was conducted to establish the relationship between DPR and the independent variables in order to test Hypothesis 2 (H2). Table 6 shows the fixedeffects panel regression model results. The 'parameter estimate' column shows the coefficients of each independent variable. The following conclusions are made from Table 6, based on the expected relationships between the dependent and independent variables, as well as the results for the full period (1999-2014), pre-recession (1999-2007) and postrecession (2008-2014) categories:

- Company size (SIZE and CLS): Hypothesis 2 states that a positive relationship is expected between company size (SIZE and CLS) and dividend payout (DPR). The SIZE variable was found to be positively related with DPR in line with the global literature (Forti et al., 2015). This suggests that large companies are more likely to pay dividends. When comparing the pre-recession and postrecession periods, it was found that SIZE was significant only at the $10 \%$ significance level $(p<0.1)$ during the post-recession period, therefore showing a decrease in its explanatory power compared to the pre-recession period where it was significant at the $1 \%$ significance level $(p<0.01)$. These results were corroborated by the statistical test conducted using the categorical variable CLS: large companies paid higher dividends compared to smaller companies at the $1 \%$ significance level $(p<0.01)$. The results therefore support Hypothesis 2 on company size and it can be inferred that company size is a significant positive factor that influences dividend payout decisions of JSE-listed industrial companies.

- Company risk (BETA and LVRG): Hypothesis 2 states that a negative relationship is expected between company systemic risk (BETA) and dividend payout, and a positive or negative relationship is expected 
TABLE 6: Results of fixed-effects panel regression analysis.

\begin{tabular}{|c|c|c|c|c|c|c|}
\hline Independent variable & Period & Parameter estimate & Standard error & $t$-statistic & $p$ & Expected relationship \\
\hline \multirow[t]{3}{*}{ SIZE } & Full period & 0.024918 & 0.007782 & 3.202 & $0.00 * * *$ & $(+)$ \\
\hline & Pre-recession & 0.034594 & 0.009182 & 3.767 & $0.00 * * *$ & \\
\hline & Post-recession & 0.019647 & 0.011069 & 1.775 & $0.08^{*}$ & \\
\hline \multirow[t]{3}{*}{ BETA } & Full period & -0.022183 & 0.017529 & -1.266 & 0.21 & $(-)$ \\
\hline & Pre-recession & -0.031176 & 0.018500 & -1.685 & $0.09 *$ & \\
\hline & Post-recession & -0.035482 & 0.011069 & -1.166 & 0.24 & \\
\hline \multirow[t]{3}{*}{ LVRG } & Full period & 0.000192 & 0.000098 & 1.959 & $0.05^{*}$ & $(+/-)$ \\
\hline & Pre-recession & 0.000191 & 0.000126 & 1.513 & 0.13 & \\
\hline & Post-recession & 0.000296 & 0.030437 & 2.014 & $0.04 * *$ & \\
\hline \multirow[t]{3}{*}{ INVEST } & Full period & -0.000260 & 0.000178 & -1.463 & 0.14 & $(-)$ \\
\hline & Pre-recession & -0.000452 & 0.000227 & -1.990 & $0.05^{*}$ & \\
\hline & Post-recession & 0.000341 & 0.000147 & 1.060 & 0.29 & \\
\hline \multirow[t]{2}{*}{ GRWTH } & Full period & -0.000563 & 0.000203 & -2.779 & $0.01 * *$ & $(-)$ \\
\hline & Pre-recession & -0.000390 & 0.000232 & -1.680 & $0.09 *$ & \\
\hline \multirow[t]{3}{*}{ PROF } & Full period & 0.002371 & 0.000487 & 4.873 & $0.00 * * *$ & $(+)$ \\
\hline & Pre-recession & 0.001297 & 0.000625 & 2.074 & $0.04 * *$ & \\
\hline & Post-recession & 0.002961 & 0.000747 & 3.966 & $0.00 * * *$ & \\
\hline \multirow[t]{3}{*}{ FCF } & Full period & -0.000065 & 0.000014 & -4.487 & $0.00 * * *$ & $(+)$ \\
\hline & Pre-recession & -0.000067 & 0.000018 & -3.649 & $0.00 * * *$ & \\
\hline & Post-recession & -0.000019 & 0.000025 & -0.742 & 0.46 & \\
\hline \multirow[t]{3}{*}{ SOLV } & Full period & -0.005669 & 0.012010 & -0.472 & 0.64 & $(+)$ \\
\hline & Pre-recession & -0.017074 & 0.016350 & -1.044 & 0.30 & \\
\hline & Post-recession & -0.007362 & 0.018951 & -0.388 & 0.70 & \\
\hline \multirow[t]{3}{*}{ LIQD } & Full period & 0.016382 & 0.013616 & 1.203 & 0.23 & $(+)$ \\
\hline & Pre-recession & 0.011004 & 0.017653 & 0.623 & 0.53 & \\
\hline & Post-recession & 0.041989 & 0.018333 & 2.290 & $0.02 * *$ & \\
\hline \multirow[t]{2}{*}{$R$-squared } & Full period & 0.04 & - & - & - & - \\
\hline & Pre-recession & 0.06 & - & - & - & - \\
\hline \multirow{2}{*}{ Adjusted $R$-squared } & Pre-recession & 0.10 & - & - & - & - \\
\hline & Post-recession & 0.13 & - & - & - & - \\
\hline \multirow[t]{3}{*}{ Fixed effects $P$ : } & Full period & 0.00 & - & - & - & - \\
\hline & Pre-recession & 0.00 & - & - & - & - \\
\hline & Post-recession & 0.00 & - & - & - & - \\
\hline
\end{tabular}

SIZE, company size; BETA, company systemic risk; LVRG, debt-equity ratio; INVEST, investment opportunities; GRWTH, sales growth; PROF, profitability; FCF, free cash flow; SOLV, net assets ratio; LIQD, current ratio.

$*, p<0.1 ; * *, p<0.05 ; * * *, p<0.01$

between debt to equity (LVRG) and dividend payout (DPR). A negative relationship was observed between BETA and DPR, suggesting that high-risk companies avoid paying dividends, which is in line with the global literature (Hellström \& Inagambaev, 2012; Makka, 2014). BETA was only significant at the $10 \%$ level $(p<0.1)$ during the pre-recession period, suggesting that JSElisted industrial companies did not consider market risk when deciding on whether or not to pay dividends. The results therefore do not support Hypothesis 2 on company systemic risk (BETA) because BETA was found not to be a significant determinant in the dividend payout decisions of JSE-listed industrial companies. Debt-equity ratio (LVRG), however, was found to be positively related with DPR over the entire study period. During the full period, the LVRG variable was only significant at the $10 \%$ level $(p<0.1)$, compared to the $5 \%$ level $(p<0.05)$ during the post-recession period. Thus, as debt increased in the capital structure of JSE-listed companies, their propensity to pay dividends also increased over the study period. Several reasons could explain the positive relationship found between LVRG and DPR variables. Firstly, South Africa has one of the most efficient and regulated equity capital markets in the world (Arko et al., 2014). As a result, companies using debt in their capital structure were likely to be highly profitable in order to access debt in the capital market and, therefore, capable of paying dividends. Secondly, the positive relationship suggests that South African corporates separated distribution decisions from capital structure decisions as indicated by Lintner (1956), opting to raise new funds for investments instead of reducing dividend payout. However, this contradicts the negative relationship found by Arko et al. (2014) when analysing South African companies over the period 1997-2007. The results therefore do not support Hypothesis 2 on debt to equity (LVRG) because LVRG was found not to be a significant determinant in the dividend payout decisions of JSE-listed industrial companies. 
- Investment opportunities (INVEST): Hypothesis 2 states that a negative relationship is expected between investment opportunities (INVEST) and dividend payout (DPR). A negative relationship was found between the INVEST and DPR variables in line with the global literature, suggesting that companies engaged in more investments exhibit lower dividend distributions (Forti et al., 2015). During the pre-recession period, the relationship was only significant at the $10 \%$ level $(p<0.1)$, while for the full period and post-recession periods the INVEST variable was insignificant, suggesting that the availability of investment opportunities generally did not influence dividend distributions of JSE-listed industrial companies. The present study did not find any supporting evidence to earlier results by Arko et al. (2014), Firer et al. (2008) and Sibanda (2016), who found that South African corporate managers consider availability of good investment opportunities when making dividend payout decisions. The results therefore do not support Hypothesis 2 on investment opportunities (INVEST) because INVEST was found not to be a significant determinant in the dividend payout decisions of JSE-listed industrial companies.

- Sales growth (GRWTH): Hypothesis 2 states that a negative relationship is expected between sales growth (GRWTH) and dividend payout (DPR). The GRWTH variable was found to be negatively related with dividend distributions. The GRWTH variable was only significant at the $10 \%$ significance level $(p<0.1)$ during the prerecession period compared to the $1 \%(p<0.01)$ and $5 \%$ $(p<0.05)$ significance levels during the post-recession and full period, respectively. This suggests that companies experiencing sales growth retained their profits to serve their working capital needs and to provide better future shareholder distributions in line with the global literature (Forti et al., 2015; Gill et al., 2010; Imran, 2011). The results therefore support Hypothesis 2 on sales growth and it can be inferred that sales growth negatively affects dividend distribution decisions of JSE-listed industrial companies.

- Profitability (PROF): Hypothesis 2 states that a positive relationship is expected between profitability (PROF) and dividend payout (DPR). The PROF variable was found to be positively related with DPR, supporting the assertions of several global studies and South African surveys that profitable companies pay higher dividends compared to their less profitable counterparts (Firer et al., 2008; Forti et al., 2015; Kapoor et al., 2010; Lintner, 1956). The PROF variable offered one of the strongest instances of explanatory power across all the periods, that is, at $1 \%$ significance level during the post-recession and full periods $(p<0.01)$ and $5 \%$ significance level during the pre-recession period $(p<0.05)$. The results therefore support Hypothesis 2 on profitability and it can be inferred that JSE-listed industrial companies consider current profit earnings when making dividend distribution decisions.

- Free cash flow (FCF): Hypothesis 2 states that a positive relationship is expected between free cash flow (FCF) and DPR. The FCF variable was negatively related with DPR, contrary to global studies that found that companies with high cash reserves paid higher dividends (Forti et al., 2015; Hellström \& Inagambaev, 2012; Musa, 2009). When comparing the three periods, the FCF variable was found significant for the full period and pre-recession period at $1 \%$ significance level $(p<$ 0.01). Despite the negative relationship and lack of support during the post-recession period, the present study results concur with previous South African studies that found that companies smooth their dividend payouts and are reluctant to change their dividend payout policies in response to temporary changes in the level of earnings (De Vries et al., 2012; Firer et al., 2008; Sibanda, 2016). In addition, JSE-listed companies only alter their dividend distribution decisions in line with changes in fundamental performance (Arko et al., 2014). It is therefore inferred that JSE-listed industrial companies consider the level of cashflows when making dividend payout decisions. The results therefore do not support Hypothesis 2 on free cash flow (FCF), because FCF was found to have a significant, but negative, relationship with DPR.

- Liquidity (SOLV and LIQD): Hypothesis 2 states that a positive relationship is expected between liquidity (SOLV and LIQD) and dividend payout (DPR). The SOLV variable was negatively related with DPR, while the LIQD variable was positively related with DPR. The LIQD variable was only a significant factor at the 5\% significance level $(p<0.05)$ during the post-recession period, whereas the SOLV variable was insignificant in all periods. These results suggest that corporate managers in South Africa started paying close attention to the current ratio (LIQD) during the post-recession period, possibly in response to the ravaging effect of the global financial crisis of 2008. When considering the results of the full period, the present study did not find any significant statistical evidence to support either the SOLV (-) or LIQD (+) variable. It can therefore be inferred that liquidity did not influence dividend payout decisions of JSE-listed industrial companies over the study period, probably because of the strict regulation that guides dividend distributions. Hypothesis 2 on liquidity (SOLV and LIQD) is therefore not supported because liquidity was found to have an insignificant relationship with DPR.

When testing hypothesis 2 , the empirical analysis results indicate that the dividend policies of JSE-listed industrial companies are significantly and positively affected by company size (SIZE and CLS) and current profit earnings (PROF) and negatively affected by sales growth (GRWTH) and free cash flow (FCF) over the full period (1999-2014) at the $5 \%(p<0.05)$ significance level. The estimates for LVRG $(+)$, BETA (-), INVEST (-), SOLV (-) and LIQD (+) were found to be insignificant factors with regard to dividend payout decisions of JSE-listed industrial companies at the $5 \%$ level of significance $(p>0.05)$. It is, therefore, concluded that large 
(SIZE and CLS), profitable (PROF) JSE-listed industrial companies enjoying lower sales growth (GRWTH) and lower levels of free cash flow (FCF) pay higher dividends.

The results of this study show that South Africa, a developing country, does not mirror the global trend of declining dividends nor does it mirror the global empirical evidence of companies with higher free cash flows paying higher dividends. The changes in the South African regulatory environment - especially the introduction of the DWT regime - seem to have contributed to the observed trends of increased dividend payouts in South Africa, while the negative relationship reported between DPR and FCF supports the evidence from prior South African studies indicating that JSE-listed companies smooth their DPRs (Arko et al., 2014; De Vries et al., 2012; Firer et al., 2008; Sibanda, 2014). The results of the present study, however, do not support the findings of previous South African studies pertaining to investment opportunities (Arko et al., 2014; Firer et al., 2008; Sibanda, 2016), the liquidity of assets (Firer et al., 2008; Sibanda, 2016) and company risk (Arko et al., 2014) being identified as significant factors affecting dividend payout behaviour. The extended period covered in the present study therefore provided evidence that regulatory changes and the impact of the global financial crisis affect the determinants that JSE-listed industrial companies consider when paying dividends.

Overall, the regression model was found to be very weak, explaining only $4 \%$ of dividend payout decisions of South African listed industrial companies. This is further evidence that the factors considered by corporate managers when making dividend decisions cannot be reduced to a single model.

\section{Conclusion and areas of further research}

Dividend payout has been the subject of debate in financial literature since Lintner's (1956) pioneering study during the late 1950s. Despite a number of global studies having been conducted, there is no universal model that explains the determinants of dividend payout decisions. The research objective of this study was twofold: to ascertain whether the global financial crisis of 2008 affected dividend payouts of JSE-listed industrial companies and to identify the factors that JSE-listed industrial companies consider when making dividend payout decisions. This study extended the period covered by previous empirical South African studies, hence including regulatory changes affecting dividend payout decisions (e.g. the introduction of share repurchases in 1999, the strengthening of liquidity and solvency requirements pertaining to distributions in 2011 and the introduction of the DWT regime in 2012) and the impact of the global recession of 2008. A robust data collection process was applied by analysing actual published financial statements data of JSE-listed industrial companies for the period 1999-2014.
This study found that, contrary to global observations, JSElisted industrial companies showed a growing propensity to pay regular dividends over the study period (1999-2014). When comparing the pre-recession period (1999-2007) with the post-recession period (2008-2014), a significant increase in dividend payout was found. This outcome reflects the positive impact of dividend distribution regulatory reforms where STC was eventually replaced with DWT, combined with the limited incentive (from a tax perspective) for companies to substitute dividends with share repurchases. The results therefore support the taxes and clienteles hypothesis.

The results of a fixed-effects panel regression analysis showed that the dividend policies of JSE-listed industrial companies were significantly and positively affected by company size and current profitability, and negatively affected by sales growth and free cash flow. The significant positive relationship between the DPR and debt to equity ratio only during the post-recession (2008-2014) period (as opposed to the insignificant relationship in the pre-recession period) indicates that JSE-listed industrial companies considered capital structure decisions independent of dividend distribution decisions, in line with the findings of Lintner (1956). The results also offer support to the company life cycle hypothesis, suggesting that companies retain all earnings in the rapid growth phase and pay out more of their earnings at maturity (Baker \& Weigand, 2015). The significant negative relationship between free cash flows and dividend payout does not support global empirical evidence but confirms the findings of previous South African studies on stable dividend policy that suggest that JSE-listed companies are reluctant to change their dividend distribution policies in response to changes in profitability and cash flows. This study did not find support for investment opportunities, the liquidity of assets and company risk being significant factors affecting the dividend payout decisions of JSE-listed industrial companies, as identified in earlier South African studies.

Further studies are required to establish the factors that influence dividend payout decisions among the companies in the resources and financial sectors. Drawing comparative insights from the different sectors will shed more light on the distribution decisions of companies listed on the JSE, one of the major equity markets in Africa.

The practical implication of this research lies in its insights on JSE-listed industrial companies since the introduction of share repurchases in 1999. Dividend distributions are still a popular distribution method for JSE-listed industrial companies, with increased dividend payouts evident in the post-recession period (1999-2014). The results of this study therefore infer that dividend-seeking clientele should target large, profitable JSE-listed industrial companies that have lower levels of sales growth and free cash flows. Although dividend payments were found to be concentrated among a few large companies, corporate managers can draw practical applications from 
empirical evidence of this study in making dividend policy decisions. Government regulatory institutions can also draw insights from the impact of the changes in the Companies Act and Income Tax Act on dividend distributions and the attractiveness of South Africa as an investment destination.

Overall, the present study showed that solving the dividend puzzle remains a challenge and requires careful attention to country-specific, company-specific and market-specific characteristics, as well as emerging substitute forms of distributions, such as share repurchases.

\section{Acknowledgements}

This research is based on a recently submitted research assignment of L. Nyere, a Master of Business Administration (MBA) graduate of the Stellenbosch University Business School.

\section{Competing interests}

The authors declare that they have no financial or personal relationships that may have inappropriately influenced them in writing this article.

\section{Authors' contributions}

L.N. was responsible for data gathering, data analysis and report writing, while N.W. was responsible for research design and supervision.

\section{Funding}

This research received no specific grant from any funding agency in the public, commercial or not-for-profit sectors.

\section{Data availability statement}

Data sharing is not applicable to this article as no new data were created or analysed in this study.

\section{Disclaimer}

The views and opinions expressed in this article are those of the authors and do not necessarily reflect the official policy or position of any affiliated agency of the authors.

\section{References}

Abor, J., \& Fiador, V. (2013). Does corporate governance explain dividend policy in SubSaharan Africa?. International Journal of Law and Management, 55(3), 201-225. https://doi.org/10.1108/17542431311327637

Adu-Boanyah, E., Ayentimi, D. T., \& Osei-Yaw, F. (2013). Determinants of dividend payout policy of some selected manufacturing firms listed on the Ghana Stock Exchange. Research Journal of Finance and Accounting, 4(5), 49-60.

Ahmed, S., \& Murtaza, H. (2015). Critical analysis of the factors affecting the dividend payout: Evidence from Pakistan. International Journal of Economics, Finance and Management Sciences, 3(3), 204-212. https://doi.org/10.11648/j. ijefm.20150303.17

Al-Kuwari, D. (2009). Determinants of the dividend policy of companies listed on emerging stock exchanges: The case of the Gulf Cooperation Council (GCC) countries. Global Economy \& Finance Journal, 2(2), 38-63.

Al-Malkawi, H. A. N., Rafferty, M., \& Pillai, R. (2010). Dividend policy: A review of theories and empirical evidence. International Bulletin of Business Administration, $9(1), 171-200$.
Analysights. (2010). Correcting for outliers. Retrieved from https://analysights. wordpress.com/2010/09/15/correcting-for-outliers/.

Arko, A. C., Abor, J., Adjasi, C. K., \& Amidu, M. (2014). What influence dividend decisions of firms in Sub-Saharan Africa? Journal of Accounting in Emerging Economies, 4(1), 57-78. https://doi.org/10.1108/JAEE-12-2011-0053

Baah, B. K., Tawiah, R., \& Opoku, F. E. (2014). Industry sector determinants of dividend policy and its effect on share prices in Ghana. Journal of Economics, Business and Finance, 2(5), 1-19.

Baker, H. K., \& Weigand, R. (2015). Corporate dividend policy revisited. Manageria Finance, 41(2), 126-144. https://doi.org/10.1108/MF-03-2014-0077

Baker, M., \& Wurgler, J. (2004). A catering theory of dividends. The Journal of Finance, 59(3), 1125-1165. https://doi.org/10.1111/j.1540-6261.2004.00658.x

Bester, P. G. (2008). Shareholder distribution choices for industrial companies listed on the JSE: Share buybacks versus dividends (Unpublished MBA research assignment). Cape Town: University of Stellenbosch, Bellville.

Black, F., \& Scholes, M. (1974). The effects of dividend yield and dividend policy on common stock prices and returns. Journal of Financial Economics, 1(1), 1-22. https://doi.org/10.1016/0304-405X(74)90006-3

Borges, M. R. (2008). Is the dividend puzzle solved? Lisbon: Instituto Superior de Economia e Gestao (ISEG). https://doi.org/10.2139/ssrn.1343782

Clayman, M. R., Fridson, M. S., \& Troughton, G. H. (2012). Corporate finance: A practical approach (2nd edn.). New Jersey: John Wiley \& Sons, Inc.

Coleman, L. (2016). Applied investment theory. Cham: Palgrave Macmillan.

DeAngelo, H., DeAngelo, L., \& Stulz, R. (2006). Dividend policy and the earned/ contributed capital mix: A test of the lifecycle theory. Journal of Financia Economics, 81(2), 227-254. https://doi.org/10.1016/j.jfineco.2005.07.005

Denis, D. J., \& Osobov, I. (2008). Why do firms pay dividends? International evidence on the determinants of dividend policy. Journal of Financial Economics, 89(1), 62-82. https://doi.org/10.1016/j.jfineco.2007.06.006

Denis, D. J., \& Stepanyan, G. (2009). Factors influencing dividends. In H. K. Baker (Ed.), Dividends and dividend policy (pp. 55-69). Hoboken, NJ: John Wiley \& Sons, Inc. https://doi.org/10.1002/9781118258408.ch4

De Vries, A., Erasmus, P. D., Hamman, W. D., \& Wesson, N. (2012). The effect of specific share repurchases on South African payout ratios: An exploratory study. Risk Governance and Control: Financial Markets and Institutions, 2(31), 7-16. https:// doi.org/10.22495/rgcv2i1art5

Fama, E. F., \& French, K. R. (2001). Disappearing dividends: Changing firm characteristics or lower propensity to pay? Journal of Financial Economics, 60(1) 3-43. https://doi.org/10.1016/S0304-405X(01)00038-1

Firer, C., Gilbert, E., \& Maytham, A. (2008). Dividend policy in South Africa. Investment Analysts Journal, 37(68), 5-19. https://doi.org/10.1080/10293523. 2008.11082500

Firer, C., Ross, S. A., Westerfield, R. W., \& Jordan, B. D. (2012). Fundamentals of corporate finance (5th edn.). New York: McGraw-Hill Education.

Forti, C. A. B., Peixoto, F. M., \& Alves, D. L. (2015). Determinant factors of dividend payments in Brazil. Revista Contabilidade \& Finanças, 26(68), 67-180. https://doi. org/10.1590/1808-057×201512260

Gill, A., Biger, N., \& Tibrewala, R. (2010). Determinants of dividend payout ratios: Evidence from United States. The Open Business Journal, 3(1), 8-14. https://doi. org/10.2174/1874915101003010008

Gordon, M. (1959). Dividends, earnings and stock prices. Review of Economics and Statistics, 41(2), 99-105. https://doi.org/10.2307/1927792

Grullon, G., Michaely, R., \& Swaminathan, B. (2002). Are dividend changes a sign of firm maturity? The Journal of Business, 75(3), 387-424. https://doi. org $/ 10.1086 / 339889$

Hartford Funds. (2016). The power of dividends: Past, present, and future. Retrieved from https://www.hartfordfunds.com/insights/featured-perspectives/Powerof Dividends.html.

Hellström, G., \& Inagambaev, G. (2012). Determinants of dividend payout ratios: A study of Swedish large and medium caps (Unpublished research assignment). Sweden: Umeå School of Business and Economics.

Imran, K. (2011). Determinants of dividend payout policy: A case of Pakistan engineering sector. The Romanian Economic Journal, 14(41), 47-60.

Jensen, M. C., \& Meckling, W. H. (1976). Theory of the firm: Managerial behavior, agency costs and ownership structure. Journal of Financial Economics, 3(4), 305-360. https://doi.org/10.1016/0304-405X(76)90026-X

JSE (Johannesburg Stock Exchange). (1999-2014). Johannesburg Stock Exchange handbook. Johannesburg: Profile Media.

JSE (Johannesburg Stock Exchange). (2017). Headline. Retrieved from https://www. jse.co.za/services/market-data/indices/ftse-jse-africa-index-series/headline.

Kapoor, S., Anil, K., \& Misra, A. (2010). Dividend policy determinants of Indian FMCG sector: A factorial analysis. Journal of Modern Accounting and Auditing, 6(9), $50-64$

Lentsoane, E. (2012). Stock price reaction to dividend changes: An empirical analysis of the Johannesburg Securities Exchange (Unpublished master's research assignment). Johannesburg: University of the Witwatersrand.

Lintner, J. (1956). Distribution of incomes of corporations among dividends, retained earnings and taxes. American Economic Review, 46(2), 97-113.

Lintner, J. (1962). Dividends, earnings, leverage, stock prices, and the supply of capital to corporations. Review of Economics and Statistics, 44(3), 243-269. https://doi. org/10.2307/1926397 
Makka, K. (2014). Increasing dividends by industrial firms on the JSE (Unpublished master's research assignment). Johannesburg: University of the Witwatersrand.

Mans-Kemp, N. (2015). The relationship between corporate governance and dividend payout ratios: A South African study. Management Dynamics: Journal of the Southern African Institute for Management Scientists, 24(2), 20-35.

Mehta, A. (2012). An empirical analysis of determinants of dividend policy: Evidence from the UAE companies. Global Review of Accounting and Finance, 3(1), 18-31.

Miller, M. H., \& Modigliani, F. (1961). Dividend policy, growth and the valuation of shares. The Journal of Business, 34(4), 411-433. https://doi.org/10.1086/294442

Moradi, M., Salehi, M., \& Honarmand, S. (2010). Factors affecting dividend policy: Empirical evidence of Iran. Poslovna izvrsnost, 4(1), 45-61.

Mtshali, N. (2016). Are dividend changes and share repurchases a good predictor of future changes in earnings? (Unpublished master's research assignment). Johannesburg: University of the Witwatersrand.

Mueller, D. C. (1972). A life cycle theory of the firm. Journal of Industrial Economics, 20(3), 199-219. https://doi.org/10.2307/2098055

Multpl. (2017). S\&P 500 dividend yield by month. Retrieved from http://www.multpl. $\mathrm{com} / \mathrm{s}$-p-500-dividend-yield/table?f=m

Musa, I. F. (2009). The dividend policy of firms quoted on the Nigerian Stock Exchange: An empirical analysis. African Journal of Business Management, 3(10), 555-566.

Nizar Al-Malkawi, H. A. (2007). Determinants of corporate dividend policy in Jordan: An application of the Tobit model. Journal of Economic and Administrative Sciences, 23(2), 44-70. https://doi.org/10.1108/10264116200700007

Nnadi, M., Wogboroma, N., \& Kabel, B. (2013). Determinants of dividend policy: Evidence from listed firms in the African stock exchanges. Panoeconomicus, 60(6), 725-741. https://doi.org/10.2298/PAN1306725N

PwC (PricewaterhouseCoopers). (2017). 2017 Africa capital market watch. Retrieved from http://www.pwc.co.za/capitalmarketwatch.

RSA (Republic of South Africa). (1962). Income Tax Act, No. 58 of 1962. Pretoria: Government Printers.

RSA (Republic of South Africa). (1999). Companies Amendment Act, No. 37 of 1999. Pretoria: Government Printers.

RSA (Republic of South Africa). (2008). Companies Act, No. 71 of 2008. Pretoria: Government Printers.

SARS (South African Revenue Services). (2017). Dividends tax. Retrieved from http:// www.sars.gov.za/TaxTypes/DT/Pages/default.aspx.
Sibanda, B. (2016). Drivers that shape corporate payout policy in South Africa (Unpublished MBA research assignment). Pretoria: University of Pretoria's Gordon Institute of Business Science (GIBS).

Sibanda, M. (2014). Do firms smooth their dividends over time? Evidence from the Johannesburg Stock Exchange. Journal of Economics, 5(3), 333-339. https://doi. org/10.1080/09765239.2014.11885009

Statistics South Africa. (2017). CPI history. Retrieved from http://www.statssa.gov.za/ publications/P0141/CPIHistory.pdf.

StatSoft Southern Africa. (2013). STATISTICA - Variance estimation and precision (VEPAC). Retrieved from https://statisticasoftware.wordpress.com/2013/01/25/ statistica-variance-estimation-and-precision-vepac/.

Straehl, P., \& Ibbotson, R. (2017). The long-run drivers of stock returns: Total payouts and the real economy. Financial Analysts Journal, 73(3), 1-21. https://doi. org/10.2469/faj.v73.n3.4

The Economist. (2014). The repurchase revolution. London: The Economist Group Limited.

Uwuigbe, O. R. (2013). Determinants of dividend policy: A study of selected listed firms in Nigeria. Manager Journal, 17(1), 107-119.

Vermeulen, M., \& Smit, E. v. d. M. (2011). Dividend payout and future earnings growth: A South African study. South African Journal of Business Management 42(4), 33-46.

Viviers, S., Firer, C., \& Muller, C. (2013). A review of the dividend payments of South African listed companies during the period 1977-2011. Management Dynamics: Journal of the Southern African Institute for Management Scientists, 22(4), 2-19.

Wesson, N., Bruwer, B. W., \& Hamman, W. D. (2015). Share repurchase and dividend payout behaviour: The South African experience. South African Journ Management, 46(3), 43-54. https://doi.org/10.4102/sajbm.v46i3.100

Wesson, N., \& Hamman, W. D. (2012). The repurchase by a holding company of treasury shares held by subsidiaries: A South African perspective. South African Journal of Business Management, 43(4), 33-44.

Wesson, N., Smit, E. v. d. M., Kidd, M., \& Hamman, W. D. (2018). Determinants of the choice between share repurchases and dividend payments. Research in International Business and Finance, 45(C), 180-196. https://doi.org/10.1016/ j.ribaf.2017.07.150

Wolmarans, H. P. (2003). Does Lintner's dividend model explain South African dividend payments? Meditari Accountancy Research, 11(1), 243-254. https://doi. org/10.1108/10222529200300015 